\title{
New record of Epistylis hentscheli (Ciliophora, Peritrichia) as an epibiont of Procambarus (Austrocambarus) sp. (Crustacea, Decapoda) in Chiapas, Mexico
}

\author{
Mireya Ramírez-Ballesteros ${ }^{1,2}$, \\ Gregorio Fernandez-Leborans ${ }^{3}$, Rosaura Mayén-Estrada'
}

I Laboratorio de Protozoología, Departamento de Biología Comparada, Facultad de Ciencias, Universidad Nacional Autónoma de México, Av. Universidad 3000, Circuito Exterior S/N. Coyoacán, 04510. Ciudad de México, México 2 Posgrado en Ciencias Biológicas, Facultad de Ciencias, Universidad Nacional Autónoma de México 3 Departamento de Zoología, Facultad de Biología, Universidad Complutense, Calle José Antonio Novais 12, 28040. Madrid, España

Corresponding author: Mireya Ramírez-Ballesteros (mballesteros@ciencias.unam.mx)

Academic editor: I. Wehrtmann | Received 4 May 2018 | Accepted 24 July 2018 | Published 16 August 2018

http://zoobank.org/59385B28-A81E-4C90-B3B7-5BADC513CA55

Citation: Ramírez-Ballesteros M, Fernandez-Leborans G, Mayén-Estrada R (2018) New record of Epistylis hentscheli (Ciliophora, Peritrichia) as an epibiont of Procambarus (Austrocambarus) sp. (Crustacea, Decapoda) in Chiapas, Mexico. ZooKeys 782: 1-9. https://doi.org/10.3897/zookeys.782.26417

\begin{abstract}
Epibiosis is very common between crustaceans and ciliates where the calcified surface of the crustacean body provides a suitable substrate for ciliate colonization. The aim of this contribution is to provide data about a new record between the epistylid ciliate Epistylis hentscheli Kahl, 1935, and the crayfish Procambarus (Austrocambarus) sp. The distribution of the epistylid on the basibiont body and its cellular/ colonial characteristics were analyzed. Procambarus (Austrocambarus) sp. harbored colonies of E. hentscheli only on the pereiopods. This is the first record of this peritrich ciliate as an epibiont on Crustacea, having been previously found on algae and fish.
\end{abstract}

\section{Keywords}

ciliate, colonies, epibiosis, epistylid, Montebello 


\section{Introduction}

Epibiosis is a facultative and interspecific association between two organisms, the epibiont and the basibiont, the latter providing a substrate for the attachment of the former (Wahl 2008). The basibionts are usually significantly larger than epibionts, have body surfaces that are physiologically inactive, and are sessile or slow-moving (Threlkeld et al. 1993; Wahl and Mark 1999). Epibiosis is a continuous and dynamic process in which the benefits and costs for basibionts and epibionts can change depending on environmental conditions (Fernandez-Leborans 2010).

Epibiotic associations between crustaceans and ciliates are very common, since the calcified surface of the crustacean functions as a semi-permanent substrate, providing an optimal habitat for epibionts ciliates, especially in those areas where other substrates are not suitable for long-term colonization (Fernandez-Leborans 2010). Among the ciliate epibionts of crustaceans, the Peritrichia (Fernandez-Leborans and Tato-Porto 2000a), Suctoria (Batisse 1994; Fernandez-Leborans and Tato-Porto 2000b) and Chonotricha (Fernandez-Leborans 2010) are the most commonly reported. Regarding the 13 species of the sessilid peritrich genus Epistylis (Table 1), so far there have been no reports of $E$. hentscheli as epibiont of crustaceans.

Ciliates of the genus Epistylis include colonial organisms with a non-contractile and branched stalk; each zooid has a well-defined peristomial lip and epistomial disc in the oral region, being the zooids elongated and generally in the shape of a vase (Lynn 2008). Procambarus (Austrocambarus) sp., a member of the family Cambaridae, is a freshwater decapod inhabiting dams, streams, and rivers. Species of this genus are considered important macro- invertebrates in temperate and tropical areas, participating in maintaining the balance in the food chain through the processes of degradation of the organic matter of the systems (Álvarez et al. 2012; Yazicioglu et al. 2016). The crayfish can represent up to $85 \%$ of the zoobenthic biomass, are considered strong engineers of the ecosystems, and can be considered as ecological regulators (Veselý et al. 2015).

The goal of this contribution is to provide data of $E$. hentscheli and its distribution on the body of the crayfish Procambarus (Austrocambarus) sp., including some cellular/ colonial characteristics of the epistylid.

\section{Materials and methods}

Sampling. Specimen of Procambarus (Austrocambarus) sp. were collected in an artificial pond of Montebello Chiapas, Mexico [16 $04.40 \mathrm{~N}, 91^{\circ} 37.40 \mathrm{~W}$ (DDM)], 1,507 $\mathrm{m}$ above sea level, during the rainy and dry seasons in years 2014-2015, being the mud and clay the principal substrate. Collections during the rainy season and the dry season were performed every three months, and in each sampling the following physical and chemical parameters were measured: water temperature, conductivity, and $\mathrm{pH}$ by a YSI model 85 multiparameter sonde and dissolved oxygen concentration was measured with an oximeter YSI model 55/12.

Technique procedures. Crustaceans were transported alive to the Protozoology laboratory (Faculty of Sciences, Universidad Nacional Autónoma de México, Mexico City), 
Table I. Species of the genus Epistylis reported previously as epibionts of freshwater decapods.

\begin{tabular}{|c|c|c|c|}
\hline Decapod host & Ciliate species & \begin{tabular}{|c|}
$\begin{array}{c}\text { Infected } \\
\text { body regions }\end{array}$ \\
\end{tabular} & Sources \\
\hline \multirow{6}{*}{$\begin{array}{l}\text { Pontastacus } \\
\text { leptodactylus } \\
\text { Eschscholtz, } 1823\end{array}$} & Epistylis sp. & \multirow{6}{*}{$\begin{array}{c}\text { Antennae } \\
\text { Carapace } \\
\text { Pleopods } \\
\text { Telson } \\
\text { Uropods } \\
\text { Gills }\end{array}$} & \multirow{6}{*}{$\begin{array}{l}\text { Zaikov et al. (2000), } \\
\text { Harlioglu (1999), } \\
\text { Hüseyin and Selcuk (2005), } \\
\text { Nekuie et al. (2015) }\end{array}$} \\
\hline & E. niagarae Kellicott, 1883 & & \\
\hline & E. chrysemidis Bishop \& Jahn, 1941 & & \\
\hline & E. astaci Nenninger, 1948 & & \\
\hline & E. cambari Kellicott, 1885 & & \\
\hline & E. crassicollis Stein, 1867 & & \\
\hline \multirow{3}{*}{$\begin{array}{l}\text { Astacus astacus } \\
\text { Linnaeus, } 1758\end{array}$} & E. astaci & \multirow{3}{*}{$\begin{array}{l}\text { Rostrum } \\
\text { Antennules } \\
\text { Antennae }\end{array}$} & \multirow{3}{*}{$\begin{array}{l}\text { Fernandez-Leborans } \\
\text { and Tato-Porto (2000a) }\end{array}$} \\
\hline & E. bimarginata Nenninger, 1948 & & \\
\hline & E. crassicollis & & \\
\hline $\begin{array}{l}\text { Cherax tenuimanus } \\
\text { Smith, } 1912\end{array}$ & Epistylis sp. & Pereiopods & Villarreal and Hutchings (1986) \\
\hline \multirow{8}{*}{$\begin{array}{l}\text { Cambarellus } \\
\text { patzcuarensis } \\
\text { Villalobos, } 1943\end{array}$} & E. bimarginata & \multirow{8}{*}{$\begin{array}{l}\text { Uropod } \\
\text { Antennules } \\
\text { Rostrum } \\
\text { Gill } \\
\text { Pereiopods } \\
\text { Pereiopod } \\
\text { Uropod } \\
\text { Telson }\end{array}$} & \multirow{8}{*}{$\begin{array}{l}\text { Mayén-Estrada and Aladro-Lubel } \\
\text { (2001) }\end{array}$} \\
\hline & E. branchiophila Perty-Stein, 1859 & & \\
\hline & E. carinogammari Stiller, 1949 & & \\
\hline & E. gammari Precht, 1935 & & \\
\hline & E. lacustris Imhoff, 1884 & & \\
\hline & E. niagarae & & \\
\hline & E. stammeri Nenninger, 1948 & & \\
\hline & E. variabilis Stiller, 1953 & & \\
\hline
\end{tabular}

and maintained alive in aquaria. Specimens were later dissected to separate the telson, pleopods, pereiopods, carapace, chelipeds, antennae, eyes, gills, and mouthparts. Peritrichs were observed with a Nikon stereoscopic microscope (SMZ 800). Photomicrographs and morphometric records were obtained using a Nikon digital camera (Digital Sight DS2Mv) adapted to a Nikon microscope (Labophot2/AX70).

Ciliates were fixed in $70 \%$ alcohol, to reveal their cellular structure with the pyridine silver carbonate technique (Fernandez-Leborans and Castro 1986), and the protargol impregnation technique (Foissner 2014). Peritrichs measurements were obtained from live and stained individuals and included: length and width of the zooid, macronucleus, stalk and also width of the peristomial collar. Epistylis hentscheli was identified based on morphological characteristics described by Foissner et al. (1992), including the measurements of length and width of the zooids, and the width of the peristomial collar. Main morphological features of this species include the shape of the zooids and tall of the entire colony.

\section{Results}

The physical and chemical parameters data recorded during the dry (DS) and rainy season (RS) of the pond, which were measured each three months were: temperature (DS: $18.7^{\circ} \mathrm{C} \pm 2.1$, RS: $21.2^{\circ} \mathrm{C} \pm 1.8$ ), $\mathrm{pH}$ (DS: $7 \pm 0.5$, RS $6 \pm 0.4$ ) conductivity (DS: $321 \mu \mathrm{S} \pm 56$, RS: $243 \mu \mathrm{S} \pm 64$ ), and dissolved oxygen (DS: $7.46 \mathrm{mg} / \mathrm{L} \pm 0.9$, $\mathrm{RS}: 8.85 \mathrm{mg} / \mathrm{L} \pm 0.87$ ). 


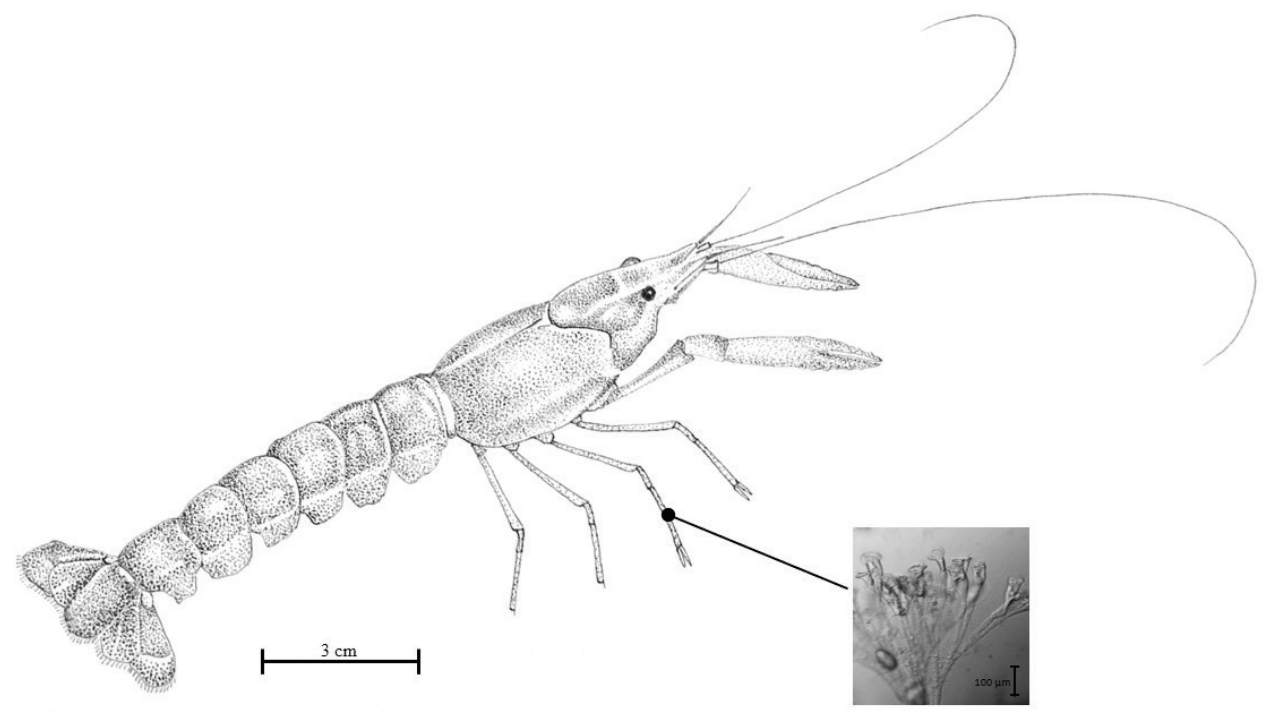

Figure I. Procambarus (Austrocambarus) sp. from Montebello, Chiapas, Mexico. Dorsal view. Colonies of Epistylis hentscheli are shown.

Ninety-six crayfish specimens were collected, 46 in the dry season and 50 in the rainy season. Epistylis hentscheli was recorded only during the dry season of year 2015 on 36 individuals of the crayfish (prevalence of $78 \%$ ), and only on pereiopods, between the merus and the carpus (Figure 1); the number of colonies on individual crayfish varied between one and three.

Forty colonies of $E$. hentscheli with 20-30 zooids were observed with a dichotomously branched pattern, with a long and rigid main stalk that contained peripheral fibers arranged longitudinally (Figure $2 \mathrm{E}$ ). The observation of 38 zooids in vivo showed uncontracted and trumpet-shaped zooids (Figure 2A, B), with a peristomial disc slightly raised above the peristome; and with the infundibulum reached more than half the length of the zooid (Figure $2 \mathrm{~B}$ ). The single contractile vacuole was located above the C-shaped macronucleus (Figure 2B, D).

From stained zooids we observed one spherical micronucleus located close to the central macronucleus (Figure 2G). The oral infraciliature comprised the haplokinety and polykineties running parallely, which made approximately one and a quarter turns around the peristomial disc. At the opening of the infundibulum the haplokinety separated from the polykinety (Figure $2 \mathrm{H}-\mathrm{I}$ ). Biometric data of $E$. hentscheli are shown in Table 2.

\section{Discussion}

The current study represents the first ever record of Epistylis hentscheli as an epibiont of Crustacea. Some ciliate species have been recorded on decapods in Mexico (López- 

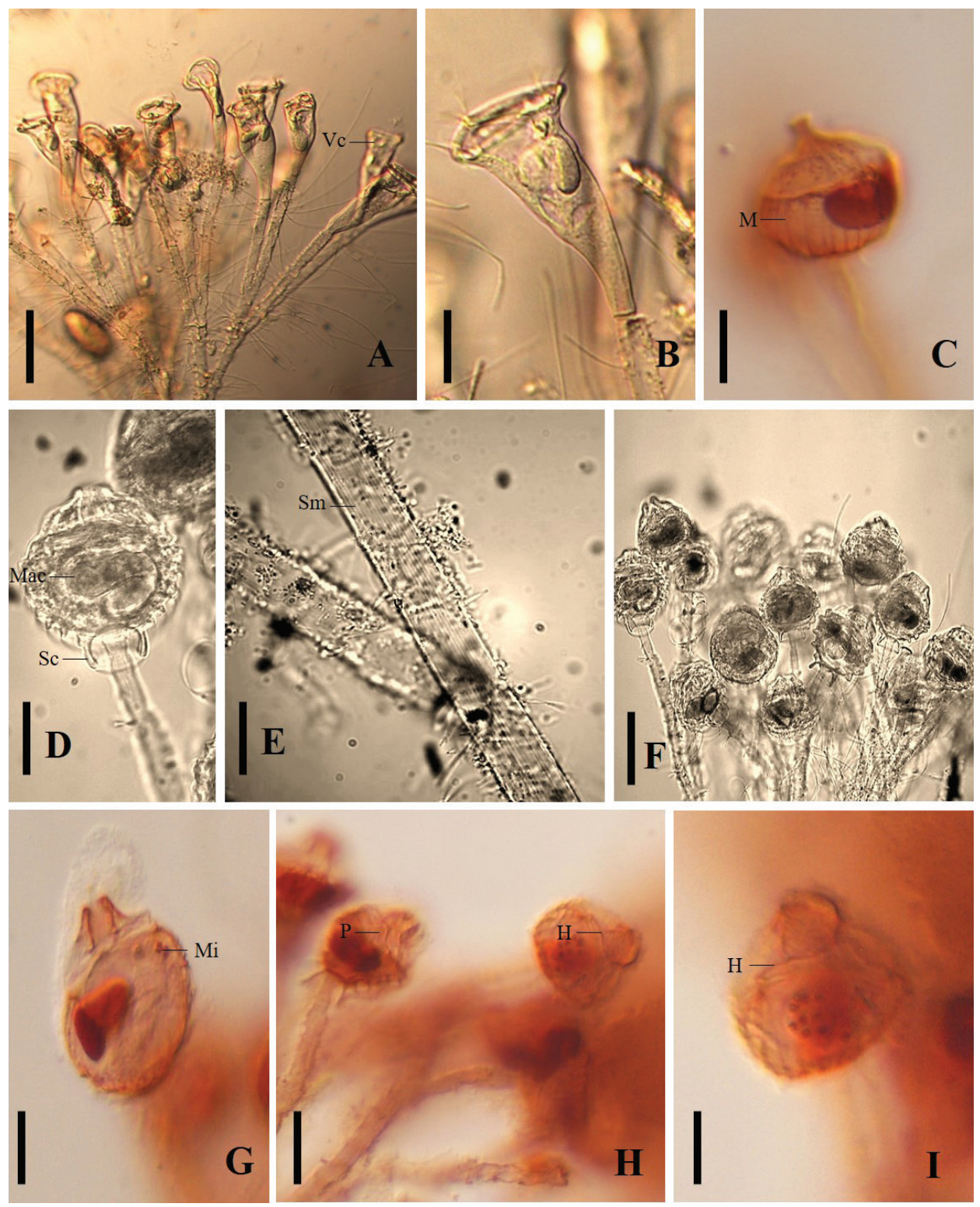

Figure 2. A-B Epistylis hentscheli in vivo, A colony B detail of zooid $\mathbf{C}-\mathbf{F}$ zooid after silver carbonate staining $\mathbf{C}$ details of myonemes and macronucleus $\mathbf{D}$ details of stalk $\mathbf{E}$ detailed longitudinal fibers in the stalk $\mathbf{F}$ colony showing contracted zooids $\mathbf{G}-\mathbf{I}$ protargol-stained zooids. Abbreviations: Cv. contractile vacuole; H. haplokinety; M. myonemes; Mac. macronucleus; Mi. micronucleus; Po. polykinety; Sc. scopula; Sm. stretch marks. Scale bars: $100 \mu \mathrm{m}(\mathbf{A}), 25 \mu \mathrm{m}(\mathbf{B}-\mathbf{D}, \mathbf{F}-\mathbf{H})$, and $10 \mu \mathrm{m}(\mathbf{E}, \mathbf{I})$.

Ochoterena and Ochoa-Gasca 1971; Mayén-Estrada and Aladro-Lubel 1998, 2000, 2001, 2002, Vidal-Martínez et al. 2002), but there are no records from Chiapas state. Epistylis hentscheli has been previously recorded as an ectoparasite of Cyprinus carpio 
Table 2. Biometric features of Epistylis hentscheli in vivo and after protargol staining, colonizing Procambarus (Austrocambarus) sp. (measurements in $\mu \mathrm{m}, \mathrm{n}=38$; Min. minimum; Max. maximum; S.D. standard deviation; C.V. coefficient of variation).

\begin{tabular}{l|c|c|c|c|c|c|c|c|c|c}
\hline \multirow{2}{*}{\multicolumn{1}{c|}{ Attribute }} & \multicolumn{4}{|c|}{ Measurements in vivo } & \multicolumn{4}{c}{ Measurements after protargol staining } \\
\cline { 2 - 13 } & Min. & Max. & Mean & S.D. & C.V & Min. & Max. & Mean & S.D. & C.V \\
\hline Zooid length & 111 & 140 & 120 & 21.4 & 0.17 & 32 & 76 & 54 & 14.6 & 0.27 \\
\hline Zooid width & 58 & 87 & 73 & 9.85 & 0.13 & 65 & 91 & 78 & 7.43 & 0.09 \\
\hline $\begin{array}{l}\text { Width of } \\
\text { peristomial collar }\end{array}$ & 62 & 90 & 76 & 9.71 & 0.12 & 20 & 34 & 28 & 4.06 & 0.14 \\
\hline $\begin{array}{l}\text { Macronucleus } \\
\text { width }\end{array}$ & 4 & 6 & 5 & 0.88 & 0.17 & 3 & 5 & 4 & 0.81 & 0.20 \\
\hline $\begin{array}{l}\text { Macronucleus } \\
\text { length }\end{array}$ & 37 & 44 & 40 & 2.46 & 0.06 & 25 & 34 & 30 & 3.05 & 0.10 \\
\hline $\begin{array}{l}\text { Primary stalk } \\
\text { length of colony }\end{array}$ & 511 & 700 & 606 & 62.7 & 0.10 & 511 & 700 & 606 & 62.7 & 0.10 \\
\hline $\begin{array}{l}\text { Primary stalk width } \\
\text { of colony }\end{array}$ & 7.3 & 7.5 & 7.4 & 0.08 & 0.01 & 7.3 & 7.5 & 7.4 & 0.08 & 0.01 \\
\hline
\end{tabular}

(Chordata, Cyprinidae) in Mexico (Herróz-Zamorano 1998), and Zaleski and Claps (2001) found this species on Enteromorpha sp. (Plantae, Chlorophyta) in Argentina.

Epistylis hentscheli colonies were formed by 20-30 zooids each and were attached to the pereiopods of Procambarus (Austrocambarus) sp. It is likely that the constant movement of these pereiopods provide a constant water flow carrying suspended food particles and oxygen to the ciliates. In contrast, the dorsal surface of the basibiont is subject to comparatively little water flow and also is exposed to more abrasion forces, possibly preventing the ciliate attachment. The ciliate colonies of E. hentscheli on the pereiopods were very long, with a stalk of $600 \mu \mathrm{m}$. This result agrees with that of Camacho and Chinchilla (1990) who reported that the location of epibiont ciliates is determined by the structural characteristics of the ciliates, and genera such as Zoothamnium, Vorticella, and Epistylis, with long stalks, adhere to body regions exposed to water currents, such as uropods and pereiopods. Fernandez-Leborans and Gabilondo (2006) and Key et al. (1997) also indicated that the adhesion site of the ciliates not only depends on the epibionts, but also depends on a series of other characteristics such as the locomotion, shape, molting period, sex, and the behavior of the crustacean.

Epibiosis is a facultative association, in which both participants gain advantages but also have disadvantages from this interaction (Fernandez-Leborans 2010). In this case, the advantage for the epibiont $E$. hentscheli is some protection against predators and a constant water flow providing food and oxygen. However, there are also some associated disadvantages, for example: the exoskeleton is molted as the crayfish grows, necessitating recolonization of the new exoskeleton by the ciliate epibiont (Mayén-Estrada and Aladro-Lubel 2000; Fernandez-Leborans and Gabilondo 2006). The advantages for the basibiont Procambarus (Austrocambarus) sp. include protection against desiccation and harmful ultraviolet radiation (Wahl 2008), while disadvantages include the alteration of the body surface and reduced efficiency of locomotion and defense (Fernandez-Leborans 2010). 


\section{Acknowledgments}

We are grateful to the Posgrado en Ciencias Biológicas, Universidad Nacional Autónoma de México, and CONACyT for a grant to MRB for master's degree. We are indebted to Dr. Villalobos-Hiriart (Instituto de Biología, UNAM) for the crustacean identification, and to M. en A. Aldi de Oyarzabal-Salcedo (Facultad de Ciencias, UNAM) for the scientific illustration. We also appreciate the technical support of Margarita Reyes-Santos (Facultad de Ciencias, UNAM), María Valladolid and Manuela Gallardo (Museo de Ciencias Naturales, CSIC). Special thanks to Dr. Alan Warren (Natural History Museum, Department of Life Sciences, UK) for his comments and assistance with the English. Finally, our sincere thanks to the people of Tziscao village for allowing us to work in their community.

\section{References}

Álvarez-Noguera F, Villalobos-Hiriart J, Armendáriz G, Hernández C (2012) Relación biogeográfica entre cangrejos dulceacuícolas y acociles a lo largo de la zona mexicana de transición: reevaluación de la hipótesis de Rodríguez (1986). Revista Mexicana de Biodiversidad 83: 1073-1083.

Batisse A (1994) Sous-Classe des Suctoria Claparède et Lachmann, 1958. In: Tomie A (Ed.) Traite de Zoologie. Tome II. Infusoires cilies. Fascicule 2. Masson, Paris, 493-563.

Camacho L, Chinchilla M (1990) Distribución de ciliados epibiontes en Macrobrachium rosenbergii (Decapoda: Natantia). Revista de Biologia Tropical 8(1): 1-5.

Fernandez-Leborans G (2010) Epibiosis in Crustacea: an overview. Crustaceana 83(5): 549-640. https://doi.org/10.1163/001121610X491059

Fernandez-Leborans G, Castro M (1986) The morphology of Anophrys arenicola n. sp. (Ciliophora, Scuticociliatida). Journal of Natural History 20: 713-721. https://doi. org/10.1080/00222938600770491

Fernandez-Leborans G, Tato-Porto M (2000a) A review of the species of protozoan epibionts on crustaceans. I. Peritrich Ciliates. Crustaceana 73(6): 643-683. https://doi. org/10.1163/156854000504705

Fernandez-Leborans G, Tato-Porto M (2000b) A review of the species of protozoan epibionts on crustaceans. II. Suctorian Ciliates. Crustaceana 73(10): 1205-1327. https://doi. org/10.1163/156854000505209

Fernandez-Leborans G, Gabilondo R (2006) Taxonomy and distribution of the hydrozoan and protozoan epibionts on Pagurus bernhardus (Linnaeus, 1758) (Crustacea, Decapoda) from Scotland. Acta Zoologica 87(1): 33-48. https://doi.org/10.1111/j.1463-6395.2006.00218.x

Foissner W (2014) An update of basic light and scanning electron microscopic methods for taxonomic studies of ciliated protozoa. International Journal of Systematic and Evolutionary Microbiology 64: 271-292. https://doi.org/10.1099/ijs.0.057893-0

Foissner W, Berger H, Kohmann F (1992) Taxonomische und ökologische. Revision der Ciliaten des Saprobiensystems. Band II: Peritrichida, Heterotrichida, Odontostomatida. Informationsberichte des Bayerischen Landesamtes für Wasserwirtschaft. München 5: 1-502. 
Harlioglu M (1999) The first record of Epistylis niagarae on Astacus leptodactylus in a crayfish rearing unit. Turkish Journal of Zoology 23: 13-15.

Herróz-Zamorano A (1998) Protozoos ciliados ectoparásitos de peces de la familia Cyprinidae cultivados en el Centro Acuícola Morelos de Zacapu, Michoacán. PhD thesis, Ciudad de México, Mexico: Universidad Nacional Autónoma de México.

Hüseyin S, Selcuk B (2005) Prevalence of Epistylis sp. Ehrenberg, 1832 (Peritrichia, Sessilida) on the narrow-clawed crayfish Astacus leptodactylus (Eschoscholtz, 1823) from Manyas Lake in Turkey. Journal of Animal and Veterinary Advances 4: 789-793.

Key J, Volpe W, Jeffries W, Voris H (1997) Barnacle fouling of the blue crab Callinectes sapidus at Beaufort, North Carolina. Journal of Crustacean Biology 17: 424-439. https://doi. org/10.2307/1549437

Lynn D (2008) The Ciliated Protozoa. Characterization, Classification and Guide to the Literature. Springer Science, Canada, 605 pp.

López-Ochoterena E, Ochoa-Gasca E (1971) Protozoarios ciliados de México. XVII. Algunos aspectos biológicos de veinte especies epizoicas del crustáceo Cambarellus montezumae zempoalensis Villalobos. Revista Latinoamericana de Microbiología 13(3): 221-231.

Mayén-Estrada R, Aladro-Lubel MA (1998) Tres especies de suctores (Protozoa: Ciliophora) ectosimbiontes del acocil Cambarellus patzcuarensis. Anales del Instituto de Biología. Universidad Nacional Autónoma de México. Serie Zoología 69(1): 1-12.

Mayén-Estrada R, Aladro-Lubel MA (2000) First record of Lagenophrys dennisi (Ciliophora: Peritrichia) on the crayfish Cambarellus patzcuarensis. Journal of Eukaryotic Microbiology 47(1): 57-61. https://doi.org/10.1111/j.1550-7408.2000.tb00011.x

Mayén-Estrada R, Aladro-Lubel MA (2001) Epibiont peritrichids (Ciliophora: Peritrichida: Epistylididae) on the crayfish Cambarellus patzcuarensis in Lake Pátzcuaro, Michoacán, Mexico. Journal of Crustacean Biology 21(2): 426-434. https://doi.org/10.1163/2002197599990143

Mayén-Estrada R, Aladro-Lubel MA (2002) Distribution and prevalence of 15 species of epibiont peritrich ciliates on the crayfish Cambarellus patzcuarensis Villalobos, 1943 in lake Pátzcuaro, Michoacán, México. Crustaceana 74: 1213-1224. https://doi. org/10.1163/15685400152885192

Nekuie F, Afsharnasab M, Seidgar M, Kakoolaki S, Azadikhah D, Asem A (2015) Protozoan epibionts on Astacus leptodactylus (Eschoscholtz, 1823) from Aras Reservoir, Northwest Iran. Iranian Journal of Fisheries Sciences 14(2): 308-320.

Threlkeld S, Chiavelli D, Willey R (1993) The organization of zooplankton epibiont communities. Trends in Ecology and Evolution 8(9): 317-321. https://doi.org/10.1016/01695347(93)90238-K

Veselý L, Buřič M, Kouba A (2015) Hardy exotic species in temperate zone: Can "warm water" crayfish invaders establish regardless of low temperatures? Scientific Reports 5: 16340. https://doi.org/10.1038/srep16340

Vidal-Martínez V, Jiménez-Cueto A, Simá-Álvarez R (2002) Parasites and symbionts of native and cultured shrimps from Yucatán, Mexico. Journal of Aquatic Animal Health 14: 57-64. https://doi.org/10.1577/1548-8667(2002)014<0057:PASONA>2.0.CO;2 
Villarreal H, Hutchings R (1986) Presence of ciliate colonies on the exoskeleton of the freshwater crayfish Cherax tenuimanus (Smith) (Decapoda: Parastacidae). Aquaculture 58(3/4): 309-312. https://doi.org/10.1016/0044-8486(86)90097-9

Wahl M (2008) Ecological lever and interface ecology: epibiosis modulates the interactions between host and environment. Biofouling 24(6): 27-38. https://doi.org/10.1080/08927010802339772

Wahl M, Mark O (1999) The facultative nature of epibiosis: experimental and observational evidence. Marine Ecology Progress Series 187: 59-66. https://doi.org/10.3354/meps187059

Yazicioglu B, Reynolds J, Kozák P (2016) Different aspects of reproduction strategies in crayfish: A review. Knowledge and Management of Aquatic Ecosystems 417: 33. https://doi. org/10.1051/kmae/2016020

Zaikov A, Karanikoloy Y, Hubenova-Siderova T (2000) Record of ectocommensalism between Epistylis sp. (Peritrichia, Sessilida, Epistylidae) and artificially cultivated narrow-clawed crayfish (Astacus leptodactylus Esch.). Bulgarian Journal of Agricultural Science 6: 575-578.

Zaleski M, Claps C (2001) First record of some peritrichs ciliates for San Miguel del Monte pond (Buenos Aires, Argentina). Gayana 65: 27-36. https://doi.org/10.4067/S071765382001000100007 